\title{
Strength Training Post-Workout Eating Habits Aiming Muscle Hypertrophy of Young Adults at two Gyms in Fortaleza-Ce
}

\author{
Tiago Menezes Caminha ${ }^{1}$, Welton Daniel Nogueira Godinho ${ }^{1}$, Jonathan \\ Moreira Lopes ${ }^{1}$, Mateus dos Santos Feitoza ${ }^{1}$, Anderson Barbosa Araújo ${ }^{2}$, \\ Paula Matias Soares ${ }^{1}$, André Accioly Nogueira Machado ${ }^{1}$
}

\begin{abstract}
Strength training is a physical activity which presents the main goal of muscle hypertrophy, and thus it is fundamental a balanced diet and a correct micronutrient intake during the recovery period. The objective of this paper was to analyze strength training post-workout eating habits of people who aim muscle growth at two gyms in the city of Fortaleza-CE. It consists of a quantitative research involving athletes within the age range of 18 to 30 years old. With the purpose of investigating their daily and after workout nourishment, a 24-hour dietary recall followed by the avanutri software was used in order to calculate calorie and macronutrient consumption. Recommendations regarding macronutrient intake after workout were adopted to evaluate the individuals' routines. Regarding the participants' daily calorie intake, $68 \%$ showed a lower and only $32 \%$ were higher consumption values than the recommended. On the other hand, 68,2\% were consuming less proteins and $32 \%$ more proteins than the necessary. Concerning the carbohydrate intake during this period, $45 \%$ of the individuals presented a consumption within the recommended range, though $41 \%$ were higher and only $14 \%$ were consuming lower quantities than the necessary.
\end{abstract}

Keywords: Nutritional evaluation; Eating habits; Muscle hypertrophy; Macronutrients.

\section{Introduction}

Strength training athletes who aim muscular hypertrophy need not only a well planned workout routine, but also a specific diet so that they can go through a more efficient muscular anabolism. Among the important nutrients which help them to reach good results, there are the macronutrients, such as carbohydrates, lipids and proteins. These nutrients are fundamental to intense training recovery. This research is important because it provides sufficient information so that researchers and professionals who work in this area can verify the postworkout eating coherence according to the nutritional needs this type of physical activity requires. This paper presents, as an objective, the analysis of the eating habits of individuals who practice strength training workout routines aiming muscle hypertrophy at two gyms in Fortaleza, Ceara.

\section{Eating Habits}

\section{Eating Habits, Strength Training And Hypertrophy}

Brazil suffers great influence by developed countries when it comes to eating habits: fast food restaurants are everywhere in big cities; whereas in France, for instance, there is a well spread gastronomic tradition for centuries, which makes it more difficult for these kinds of products, considered symbols of modernity. The increase in meat consumption observed in less wealthy communities is related to their social ascension potential and to the satiety meat intake promotes. A higher ingestion of bread and a lower consumption of beans and cassava flour indicate a new habit: substituting dinner for snacks. It can also be observed that it is still inconspicuous people's concerns towards health and the pursuit of healthy food (BLEIL, 1998). According to Barbosa (2009), the Brazilian population are used to having from three to four meals a day, which goes against the medical and nutritional recommendations (six meals a day), however this does not mean that Brazilians do not consume anything in between their meals, they just do not consider small snacks as meals. In a study performed with students of health areas in Brasilia, it was verified that $79,7 \%$ of these students have eating habits that are considered inadequate, highlighting a significant amount of these individuals who consumes soda, sweet food. Only one type of animal protein and leguminous plants showed adequate intake by an expressive percentage (MARCONDELLI, COSTA; SCHIMITZ, 2009).

\section{Macronutrients}

Macronutrients are big structures that are consumed in large quantities and, in order to be absorbed by the organism, they need to be broken down and transformed into smaller unities. After this, these substances provide energy to the organism through a complex biochemical process named metabolism (TIRAPEGUI, 2005). 
This kind of nutrients not only play the role of the organism biological fuel, but it also maintains both its structural and functional integrity (MCARDLE, KATCH; KATCH, 1999). Energy production through carbohydrates is twice as big as through fat, thus the former is the main energy resource to Adenosine Triphosphate production (ATP) (BOMPA; CORNACCHIA, 2000). In active people, carbohydrates provide approximately $60 \%$ of the total daily calories $(400$ to $600 \mathrm{~g}$ ). This quantity supplies muscular glycogen, improving physical activities (MCARDLE, KATCH; KATCH. 1999). Fat is metabolized in a very slow path, whereas carbohydrates synthesize ATP at the speed of $1.0 \mathrm{~mol} /$ minute. The lipid ATP synthesis occurs at the speed of only $0.5 \mathrm{~mol} /$ minute, two times slower, proving that humans' organisms find it more difficult to synthesize fat (BOMPA; CORNACCHIA, 2000). Proteins are fundamental on any diet, because they are processed in order to repair e build muscular fibers. During intense training periods, the inadequate protein ingestion can lead to a protein degradation rate higher than its synthesis rate, causing muscular tissue loss (BOMPA; CORNACCHIA, 2000).

\section{Strength Training and Muscular Hypertrophy}

Strength training embraces many types of training systems and it is also known as weight training or load training. It can improve body composition, strength development, motor performance and muscular hypertrophy. There are many validated training systems which demonstrate several possibilities of manipulating basic training variables. Strength development and muscular growth depend on the correct combination of different factors and on the right manipulation of different training variables (FLECK; KRAEMER, 1999).

With an adequate stimulus, against weight forces (resistance) exercises should be used for both muscular hypertrophy and lean body mass preservation, especially muscle and bones for people at any age and of any gender (MARCHAND, 2009).

A similar study, performed during 16 weeks of training and with 38 men at the average age of 23 years old, verified that in the first eight weeks there were strength increase and muscle growth, whereas only the former occurred in the other eight weeks, concluding that there was a higher impact on muscular hypertrophy during the first weeks (NASCIMENTO et al., 2007). Old people who practiced strength training improved their lean body mass maintenance because of the efficiency of this type of training concerning metabolic neuromuscular variables, minimizing the sarcopenia (MAIOR, 2009). The first adaptations in a strength training program is strength increase through a neural facilitation which, in a long term, will culminate in muscular hypertrophy and bigger strength gains. The increase in muscular volume results in a greater strength production, because there are more myofibrils and sarcomeres available to perform an activity. There are also other relevant adaptations: increase in the content of phosphocreatine and glycogen and in glycolytic capacity, decrease in mitochondrial capacity and improvement in muscle buffering capacity (MAUGHAN, GLEESON; GREENHAFF, 2000).

Muscle hypertrophy training optimizes adenosine triphosphate and creatine (ATP/CP) reserves, increases muscle mass and improves the body muscle proportion. The duration of this type of training depends on several factors, such as the individual's physical condition and intensity and periodization of the trainings (BOMPA; CORNACHHIA, 2000). During strength trainings that aim muscular growth, it is necessary maximum intensity, in which determined exercises should be executed until the muscles are not able to perform another repetition any longer, avoiding stagnation points. High intensity is fundamentally important when it comes to muscular volume increase, i.e., low intensity trainings should only be adopted during recovery periods (VERKHOSHANSKI, 2000). In a past study, hypertrophy and endurance trainings were compared during the same training session, and it showed that, when individuals use both methods in the same session, it can lead to a fatigue or even to an over-training scenario. However, these two categories may be practiced in different days in order to achieve better results (BUCCI et al., 2005).

\section{Strength Training $x$ Post Workout Nourishment}

Consuming carbohydrates after physical exercises is fundamental, because it provides muscular glycogen and facilitates protein synthesis, although individuals who practice strength trainings with excessive eccentric contraction during repetitions usually present difficulties on restoring muscular glycogen (probably due to an elevated number of induced microinjuries). It is recommended that athletes consume high glycemic index carbohydrates (glucose, baked potato, mashed potato, white bread, watermelon, etc.), which are rapidly digested and available on their blood stream. Studies also prove that consuming essential aminoacids after working out improves protein synthesis and thus the protein anabolism (BACURAU et al., 2001). In order to optimize muscular recovery in intense activities, consuming $10 \mathrm{~g} / \mathrm{kg}$ per weight/day of carbohydrates is the recommended dosage, although it was also mentioned that individuals should eat from 0.7 to $1.5 \mathrm{~g} / \mathrm{kg}$ per weight within the interval of 4 hours after an exhaustive exercise (SOCIEDADE BRASILEIRA DE MEDICINA DO ESPORTE, 2003). 
During the post-workout period, the glucose ingested is deviated towards glycogen re-synthesis, which occurs in two phases: the first one is independent of insulin, whereas the second depends on it (TIRAPEGUI, 2006). Rasmussen et al. (2000) analyzed, on their study, the usage of a supplement composed of essential aminoacids and carbohydrates after endurance exercises and how it was related to protein anabolism. 3 men and 3 women participated in this research. The beverage consisted of 6 grams of essential aminoacids and 35 grams of sucrose, and the individuals drank it after 1 and 3 hours past the exercise. The verification of the protein anabolism was performed through a muscular biopsy, and the research concluded that drinking this mixture 1 and 3 hours after working out produced a similar response by the organisms and that, in both cases, there was an increase of protein anabolism.

\section{Indentations And Equations}

On Figure 1, it was observed that $63.6 \%$ of the individuals are consuming a total of calories below daily recommendations, $9.1 \%$ consume an amount of calories between the recommended range, and $27.3 \%$ consume more calories than the recommended, according to the total energy expenditure calculations (GALIZA, ESPERANÇA; DE SÁ, 2008). Individuals who eat less calories than what is suggested not only become incapable of achieving hypertrophic gains through strength trainings, but they also present an intense fatigue after working out. An insufficient calorie ingestion for more than two weeks reduces the quantity of nutrients necessary to maintain adequate physiological processes in a healthy human being (DRI, 2005; KLEINER \& ROBINSON, 2005). Individuals who consume an adequate value of daily calories or above what is recommended should be able of achieving muscular anabolism if the macronutrient distribution is also following the recommendations to this type of training. However, consuming a very high quantity of calories can promote nutrient deposition on people's bodies as fat in the adipose tissue. On Table 1, the protein consumption is above the daily recommendations, because, according to Tirapegui (2005), it should not exceed 15\% of the total calorie value on the diet. As per Wolinsky and Hickson (2002), consuming elevated quantities of proteins can cause serious health problems, such as kidney pathologies, osteoporosis or even hypercholesterolemia. Also, if the daily calorie consumption is above the recommended values, the remainder and not metabolized protein can be turned into fat.Carbohydrate consumption is below the suggested values of 60 to $70 \%$, which can also be observed on the lipid consumption (slightly less than the recommended 30\%) (SOCIEDADE BRASILEIRA DE MEDICINA DO ESPORTE, 2003). This insufficient ingestion of carbohydrates turns it more difficult to restore muscular glycogen, negatively affecting muscular performance on strength training (TIRAPEGUI, 2005). Although the daily protein consumption is above the recommended values, it is possible to verify, on Figure 2 (6), that $54.5 \%$ of the individuals consume less protein on post-workout periods than what is suggested, whereas $18.2 \%$ consume the right amount within the recommended range and $27.3 \%$ are consuming more than the suggested quantity. Individuals who are consuming a protein-poor diet during this strength training period will probably present a decrease on their performance quality, followed by a lean body mass loss. However, those who are eating the correct amount of proteins or more than what is recommended will be promoting better environment to the muscular hypertrophy process if the carbohydrate consumption is also adequate on the same period (BACURAU et al., 2001; KLEINER; ROBINSON, 2005).

According to Figure 3, 45.45\% of the individuals are consuming the correct post-workout dosage of carbohydrates, $40.91 \%$ are eating more than the recommended values and only $13.64 \%$ show a less than the recommended post-workout carbohydrate intake. Those who present a right consumption of sugars are favoring muscle growth due to a satisfactory supply of muscular and hepatic glycogen during the most important period regarding hypertrophy. The individuals with a carbohydrate-poor diet will probably present reduction on their performance quality due to a fast muscular fatigue. In addition, it is possible that these individuals are using protein to satisfy their energy needs, thus promoting muscular catabolism in order to obtain energy. Those strength training athletes who are consuming an elevated amount of carbohydrates are subject to the transformation of the unused part of this nutrient into lipid, followed by its deposit on fat tissues (BACURAU et al., 2001; KLEINER; ROBINSON, 2005; TIRAPEGUI, 2005).

\section{Figures And Tables}
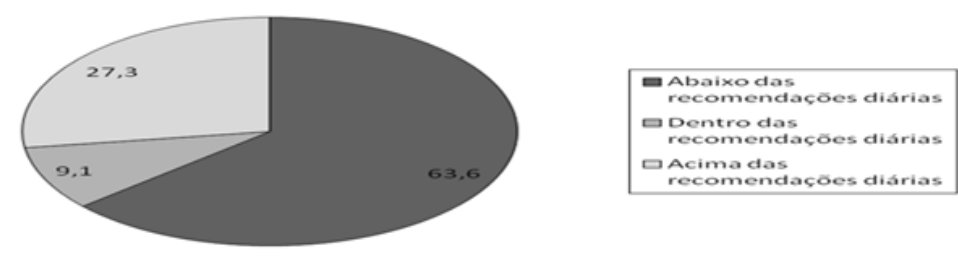

Figure 1 - Daily calorie recommendations of individuals who practice strength training aiming muscular hypertrophy at two gyms in Fortaleza $(n=22)$. 

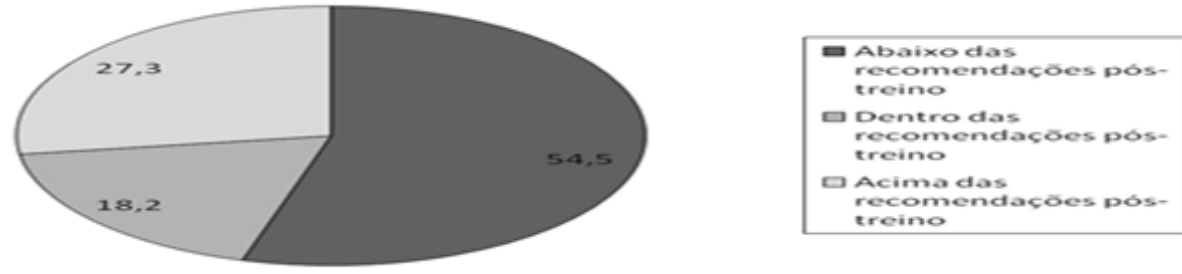

recomer treino

Figure 2 - Protein post-workout recommendations per body weight $(\mathrm{kg})$ of individuals who practice strength training aiming muscular hypertrophy $(\mathrm{n}=22)$

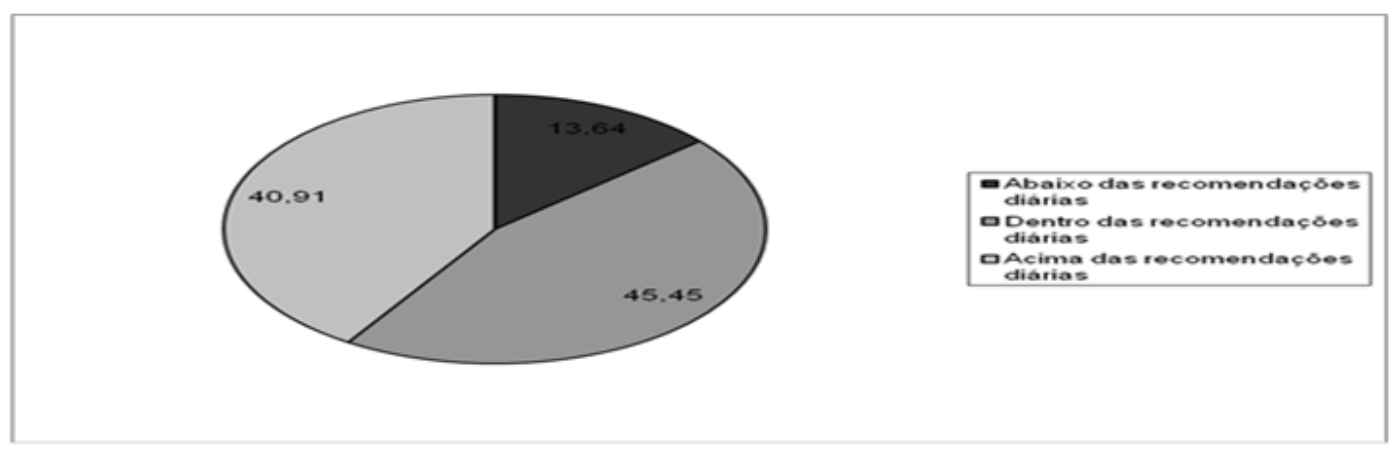

Figure 3 - Post-work carbohydrate recommendations per body weight $(\mathrm{kg})$ of individuals who practice strength training aiming muscular hypertrophy $(\mathrm{n}=22)$.

Table 1 - Daily calorie recommendations of individuals who practice strength training aiming muscular hypertrophy at two gyms in Fortaleza $(\mathrm{n}=22)$.

\begin{tabular}{|l|l|l|l|}
\hline & Proteins & Carbohydrates & Lipids \\
\hline Average & 19,9 & 52,97 & 27,13 \\
\hline Standard Deviation & 4,3 & 6 & 6,3 \\
\hline Minimum & 12,3 & 39,1 & 17,6 \\
\hline Maximum & 27,6 & 61,08 & 38,3 \\
\hline
\end{tabular}

\section{Conclusion}

Most of the individuals who practice strength training exercises aiming muscular hypertrophy presented an insufficient post-work protein consumption, which could encumber the protein synthesis and, therefore, the muscular anabolism processes. The carbohydrate consumption during the post-workout strength training period is within the recommended limits, but the inadequate ingestion of daily calories reduces the muscular hypertrophy results. Strength training post-workout nourishment is very important to those who aim muscle growth, so the correct ingestion of carbohydrates and proteins is fundamental to a proper supply of muscular and hepatic glycogen, as well as to the protein synthesis, which will provide higher muscular hypertrophy benefits.

\section{References}

[1] S. I. BLEIL. O padrão Alimentar Ocidental: considerações sobre a mudança de Hábitos no Brasil. Revista Cadernos de Debate. Campinas, v. 6, p.1- 25, 1998. Disponível em: www.unicanp.br. Acesso em: 01 de ago. 2009

[2] A.L. BARBOSA. Feijão com arroz e arroz com feijão: o Brasil no prato dos brasileiros. Horizontes Antropológicos. Porto Alegre, v. 13, n. 28, jul./dez. 2007. Disponível em: www.scielo.com.br. Acesso em: 28 de jul. 2009.

[3] P. MARCONDELLI; T.M. COSTA; B.A.S. SCHIMITZ. Nível de atividade física e hábitos alimentares de universitários do $3^{\circ}$ ao $5^{\circ}$ semestres da área da saúde. Revista de Nutrição, Campinas, v. 21, n. 01, p.01-15, fev. 2008. Disponível em: www.scielo.com.br. Acesso em: 15 jul. 2009.

[4] J. TIRAPEGUI. Nutrição, Metabolismo e Suplementação na Atividade Física. (1.ed. São Paulo: Ateneu, 2005.)

[5] W.D. MCARDLE; F.L. KATCH; V.L. KATCH. Nutrição: Para o Desporto e o Exercício. (U.S.A: Guanabara Koogan s.a., 1999. 39)

[6] T.O. BOMPA; L.J. CORNACCHIA. Treinamento de força consciente. (1. ed. São Paulo: Phorte Editora, 2000.)

[7] S.J. FLECK; W.J. KRAEMER. Fundamentos do Treinamento de Força Muscular. (2. ed.Porto Alegre: Artmed, 1999.)

[8] E.A.A. MARCHAND. Melhoras na força e hipertrofia muscular, provenientes dos exercícios resistidos. Revista Digital. Buenos Aires, v. 8, n. 57, fev. 2003. Disponível em: www.efdeportes.com. Acesso em: 25 de jul. 2009.

[9] M.A. NASCIMENTO et al. Efeito de 16 semanas de treinamento com peso sobre indicadores de força e hipertrofia muscular. Revista da Educação Física/UEM. Maringá, v.18, p. 90- 93, 2007.

[10] A.S. MAIOR. Relação Sarcopenia e Treinamento de Força. Rev. Fisioter. UNICID. São Paulo, v. 3, n. 2, p. 125- 139, jul./dez. 2004. Disponível em: www.boletimef.org. Acesso em: 25 de jul. 2009. 
[11] R. MAUGHAN; M. GLEESON; P.L. GREENHAFF. Bioquímica do Exercício e Treinamento. (1. ed.São Paulo: Manoele Ltda, 2000.)

[12] Y.V. VERKHOSHANSKI. Hipertrofia Muscular. (1. ed. Rio de Janeiro: Nei Pereira Editora LTDA, 2000.)

[13] M. BUCCI et al. Efeitos do treinamento concomitante hipertrofia e endurace no músculo esquelético. Revista Brasileira Saúde e Movimento. São Paulo, v. 13, p. 17- 28, 2005.

[14] R.F. BACURAU et al. Hipertrofia Hiperplasia: Fisiologia, nutrição e aspectos atuais. (1. Ed. São Paulo: Phorte Editora, 2001.)

[15] SMBE. SOCIEDADE BRASILEIRA DE MEDICINA DO ESPORTE Modificações dietéticas, reposição hídrica, suplementos alimentares e drogas: Comprovação de ação ergogênica e potenciais riscos à saúde. Diretriz da Sociedade Brasileira de Medicina do Esporte. Revista Brasileira de Medicina do Esporte. São Paulo, v.9, n.2, p. 1-13, mar./abr. 2003.

[16] J. TIRAPEGUI. Nutrição Fundamentos e Aspectos Atuais. (1. ed. São Paulo: Ateneu, 2006.)

[17] B.B. RASMUSSEN et al. An oral amino acid-carbohydrate supplement enhances muscle protein anabolism after resistance exercise. J. Appl. Physiol. Galveston, v.88, p. 386-392, 2000.

[18] M.S. GALIZA;L.M.B. ESPERANÇA; N. G. DE SÁ. Nutrição: conceitos e aplicações. (São Paulo: M. Books, 2008.)

[19] DRI, Institute of Medicine Food And Nutrition Board. Dietary references intakes for energy, carbohydrate, fiber, fat, fatty acids, cholesterol, protein and aminoacids. (Washington, National Academy Press, 2005.)

[20] S.M. KLEINER; M. GREENWOOD- ROBINSON. Nutrição para o Treinamento de Força. (3. ed. Barueri: Manole, 2002.)

[21] J.F. WOLINSKY; J.F. HICKSON JÚNIOR. Nutrição no Exercício e no Esporte. (2. ed. São Paulo: Roca, 2002.) 